\title{
Hubungan Minat Membaca dan Kemampuan Memahami Wacana dengan Keterampilan Menulis Narasi
}

\author{
Anggi Purwa Nugraha ${ }^{1}$, Zulela MS $^{2}$, Totok Bintoro ${ }^{3}$ \\ ${ }^{1}$ Program Pascasarjana Universitas Negeri Jakarta, Jl. Rawamangunmuka ,Jakarta Timur \\ ${ }^{2}$ Program Pascasarjana Universitas Negeri Jakarta, Jl. Rawamangunmuka ,Jakarta Timur \\ ${ }^{3}$ Program Pascasarjana Universitas Negeri Jakarta, Jl. Rawamangunmuka ,Jakarta Timur \\ *Corresponding author: anggi.purwa@student.upi.edu; zulelams@yahoo.co.id; t.bintoro@gmail.com
}

Diterima 6 Mei 2018; Direview 9 Mei 2018; Diterima 17 Mei 2018

Diterbitkan online 4 Juni 2018

\begin{abstract}
Abstrak
Penelitian ini bertujuan untuk mengetahui hubungan minat membaca dan kemampuan memahami wacana dengan keterampilan menulis narasi Siswa Kelas V Sekolah Dasar Negeri di Kecamatan Sukaraja gugus satu, dengan jumlah siswa sebanyak 112 orang siswa. Teknik yang digunakan untuk menganalisis data adalah teknik statistik regresi dan korelasi Hasil penelitian menunjukan bahwa ada korelasi positif antara (1) Minat membaca dengan keterampilan menulis narasi (2) Kemampuan memahami wacana dengan keterampilan menulis narasi (3) Minat membaca dan kemampuan memahami wacana dengan keterampilan menulis narasi. Berarti hasil penelitian, dapat disimpulkan bahwa terdapat hubungan antara minat membaca dan kemampuan memahami wacana dengan keterampilan menulis narasi.
\end{abstract}

Kata Kunci: Minat Membaca, Kemampuan Memahami Wacana, Keterampilan Menulis Narasi.

\section{PENDAHULUAN}

Dalam pembelajaran Bahasa Indonesia terdapat empat keterampilan yang harus dikuasai oleh siswa, adapun empat keterampilan tersebut diantaranya, keterampilan menyimak, keterampilan berbicara, keterampilan membaca, dan keterampilan menulis. Penguasaan empat keterampilan tersebut dikuasai oleh siswa secara bertahap.

Menulis merupakan keterampilan terakhir yang harus dikuasi oleh siswa dalam pembelajaran Bahasa Indonesia. Keterampilan menulis merupakan keterampilan yang paling sulit diantara keterampilan berbahasa yang lain. Pernyataan tersebut sebagaimana pendapat Nurgiantoro, (2012, hlm.442) menyatakan bahwa dibanding tiga kompetensi bahasa yang lain, kompetensi menulis secara umum boleh dikatakan lebih sulit dikuasai bahkan oleh penutur asli bahasa bersangkutan sekalipun. Sejalan dengan pendapat tersebut menurut Heaton (dalam Zulela, 2013, hlm.28) menyatakan bahwa menulis adalah suatu kegiatan yang kompleks dan kadang-kadang sulit diajarkan. Hal ini karena menulis bukan hanya sekedar menguasai kosa kata dan susunan kalimat yang efektif, tetapi membutuhkan berbagai kemampuan yang menunjang tercapainya keterampilan menulis.

Keterampilan menulis di sekolah dasar 
diwujudkan melalui pembelajaran Bahasa Indonesia, yang mana diantara tujuan pembelajaran Bahasa Indonesia yaitu agar siswa mampu berkomunikasi secara efektif dan efisien sesuai dengan etika yang berlaku, baik itu secara lisan maupun tulisan. Adapun salah satu kompetensi yang harus dikuasai siswa dalam pembelajaran Bahasa Indonesia di kelas V SD adalah menulis karangan berdasarkan pengalaman dengan memperhatikan pilihan kata dan menggunakan ejaan. Berdasarkan kompetesi tersebut, maka siswa diharapkan mampu mengungkapkan ide atau pikiran kedalam bentuk tulisan yang salah satunya berbentuk tulisan narasi.

Tulisan narasi merupakan bentuk tulisan yang mengambarkan suatu peristiwa secara berurutan. Hal ini sebagaimana pendapat Gorys Keraf (dalam Zulela, 2013, hlm.35) menyatakan bahwa narasi adalah suatu bentuk wacana yang berusaha menggambarkan dengan jelas kepada pembaca suatu peristiwa yang telah terjadi yang dijalin dalam suatu kesatuan waktu. Dengan kata lain menulis narasi berarti menceritakan suatu peristiwa atau kejadian yang terjadi pada kurun waktu tertentu dengan menggunakan bahasa tulis.

Mengingat bahwa keterampilan menulis merupakan suatu hal yang kompleks maka untuk mencapai keterampilan menulis dipengaruhi oleh beberapa faktor baik itu yang berasal dari dalam diri siswa maupun yang berasal dari luar diri siswa. Menurut Djibran (dalam Putu, 2017, hlm.94) menulis adalah mengungkapkan pikiran, perasaan, pengalaman, dan hasil bacaan dalam bentuk tulisan, bukan dalam bentuk tutur. Dari pendapat tersebut dapat dipahami bahwa hasil membaca yang dilakukan seseorang akan memberikan dampak terhadap hasil tulisan. Sehingga dapat dikatakan bahwa minat baca merupakan modal awal bagi siswa untuk memperoleh pengetahuan dan menjadi salah satu faktor untuk menumbuhkan ide-ide dalam kegiatan menulis.

Membaca sebagai salah satu aktifitas penting dalam perkembangan kemampuan berfikir siswa, dengan membaca kemampuan berfikir siswa akan terasah dan berkembang serta pengetahuan akan informasi pada siswa akan semakin luas. Membaca merupakan gerbang utama memasuki dunia informasi dan pengetahuan. Membaca adalah salah satu kegiatan yang tidak bisa dipisahkan dalam dunia pendidikan, karena kegiatan membaca merupakan suatu proses transformasi ilmu melalui cara melihat dan memahami isi yang tertulis di dalam sebuah buku pengetahuan maupun buku pelajaran. Sehingga dengan proses tersebut siswa akan senantiasa memperoleh pengetahuan baru dan wawasan baru yang akan meningkatkan kecerdasannya.

Pengembangan minat baca siswa di Sekolah Dasar merupakan salah satu nilai penting yang harus dikembangkan. Hal ini kerena minat baca menjadi salah satu kunci kemajuan suatu bangsa karena penguasaan ilmu pengetahuan dan teknologi akan dirahi dengan minat baca tinggi bukan hanya 
sekedar melalui kegiatan menyimak dan mendengarkan semata. Lilawati (dalam Rahadian dkk, 2014, hlm.31) mengartikan minat baca adalah suatu perhatian yang kuat dan mendalam disertai dengan perasaan senang terhadap kegiatan membaca sehingga dapat mengarahkan seseorang untuk membaca dengan kemauannya sendiri. Minat membaca adalah sumber motivasi kuat bagi seseorang untuk menganalisa dan mengingat serta mengevaluasi bacaan yang telah dibacanya, yang merupakan pengalaman belajar menggembirakan dan akan mempangaruhi bentuk serta intensitas seseorang dalam mencapai cita-citanya kelak di masa yang akan datang karena melalui membaca akan berdampak positif bagi seseorang.

Dalam hal minat baca Indonesia masih menduduki posisi yang rendah dibanding Negara-negara lain. Berdasarkan data CSM jumlah buku yang dibaca siswa SMA di 13 negara, termasuk Indonesia sangat menyedihkan. Di Amerika Serikat, jumlah buku yang wajib dibaca sebanyak 32 judul buku, Belanda 30 buku, Prancis 30 buku, Jepang 22 buku, Swiss 15 buku, Kanada 13 buku, Rusia 12 buku, Brunei 7 buku, Singapura 6 buku, Thailand 5 buku, dan Indonesia 0 buku. Kemudian berdasarkan data dari pusat Statistik (BPS) yang dilakukan pada tahun 2012 mengungkapkan bahwa hanya $17,66 \%$ anak-anak Indonesia yang memiliki minat baca, sementara yang memiliki minat menonton mencapai $91,67 \%$.
Artinya hanya ada 1 dari 10 anak di Indonesia yang memiliki minat baca, dan 9 dari 10 anak Indonesia lebih menyukai menonton televisi. Kemudian berdasarkan studi Most Littered Nation In the Word yang dilakukan oleh Central Connecticut State University pada Maret 2016, Indonesia dinyatakan menduduki peringkat ke-60 dari 61 negara soal minat membaca. Indonesia persis dibawah Thailand (59) dan di atas Bostwana (61).

Mengacu pada data tersebut pemerintah melalui kemendikbud pada tahun 2016 mengembangkan gerakan literasi sekolah (GLS) berdasarkan sembilan agenda prioritas (Nawacita) yang menjadi prioritas kerja dari presiden dalam mengembangkan bangsa Indonesia agar mampu bersaing dengan bangsa lain. Gerakan literasi tersebut dilaksanakan dengan menugaskan setiap siswa untuk membaca buku sebelum jam pelajaran dimulai. Melalui pembiasan tersebut diharapkan akan meningkatkan minat baca siswa yang masih rendah kemudian meningkatkan kemampuan intelektual siswa sehingga mempunyai wawasan yang luas.

Upaya menumbuhkan minat baca bagi siswa dalam proses pendidikan ini sejalan pula dengan Undang-undang Nomor 20 Tahun 2003 tentang Sistem Pendidikan Nasional pasal 4 ayat 5 dinyatakan bahwa "Prinsip penyelenggaraan pendidikan adalah dengan mengembangkan budaya membaca, menulis, dan berhitung bagi segenap warga masyarakat". Melalui kegiatan membaca akan menjadikan siswa belajar sepanjang hayat, 
apalagi bagi usia siswa Sekolah Dasar yang masih memiliki rasa ingin tahu terhadap suatu hal sangat tinggi, maka harus didukung dengan ketersediaan bahan bacaan dan bimbingan serta mengarahkan siswa tersebut supaya dapat memenuhi kebutuhannya.

Dalam kegiatan membaca tidak serta merta hanya melakukan kegiatan membaca pada buku-buku yang ada, tetapi dari kegiatan membaca tersebut harus mampu memahami isi yang terkandung yang disampaikan oleh penulis melalui bacaan tersebut. Kemampuan membaca pemahaman merupakan sebuah proses interaktif yang melibatkan pembaca, bacaan dan konteks. Keterampilan ini melibatkan kemampuan untuk memperoleh makna dari teks tertulis seperti yang dikemukakan oleh Silliman dan Wilkinson (dalam herlina, 2016, hlm.30) bahwa: Reading comprehension is generally defined as the ability to acquire meaning from written text. Melalui proses membaca pemahaman, para pembaca mendapatkan pemahaman dari teks yang dibacanya berkaitan dengan informasi maupun kosakata baru. Pendapat tersebut sejalan dengan Tarigan yang mengemukakan bahwa salah satu syarat memahami isi wacana yaitu pengetahuan kosa kata. Kosa kata yang dimiliki oleh siswa akan memberikan kontribusi dalam upaya memahami isi bacaan, semakin tinggi tingkat penguasaan kosa kata pada siswa maka akan semakin baik pula pemahaman siswa terhadap suatu wacana dalam bacaannya.

Kemampuan memahami wacana merupakan kemampuan yang harus dicapai oleh siswa melalui kegiatan membaca. Kemampuan memahami wacana menunjuk kepada kemampuan untuk memahami maksud dan pikiran seseorang secara eksplisit maupun implisit yang diungkapkan secara tertulis melalui wacananya. Sehingga dari kemampuan tersebut akan memberikan kontribusi bagi pencapaian keterampilan berbahasa yang terakhir yaitu keterampilan menulis.

Tarigan menjelaskan bahwa dalam kegiatan menulis, penulis haruslah memanfaatkan grafologi, struktur bahasa, dan kosa kata. Sejalan dengan pendapat tersebut Al-qarni menyatakan bahwa membaca membantu mengembangkan pemikiran dan menjernihkan cara berfikir, meningkatkan pengetahuan seseorang, serta meningkatkan memori dan pemahaman. Berdasarkan hal tersebut dapat disimpulkan bahwa keterampilan menulis seseorang haruslah ditunjang dengan minat membacanya disertai dengan mamahami isi bacaan guna memberikan ide-ide untuk menulis.

Dengan demikian berdasarkan pemaparan di atas dapat dipahami bahwa minat baca mempunyai hubungan yang signifikan terhadap kemampuan menulis siswa. Menulis dan membaca adalah kedua hal yang saling menunjang dan melengkapi artinya, kebiasaan menulis tidak mungkin terlaksana tanpa diikuti kebiasaan membaca, sebaliknya membaca tidak mungkin bermakna tanpa kebiasaan menulis. Semakin tinggi minat baca 
siswa, maka semakin tinggi keterampilan menulis (Satini, 2015, hlm.xx..). Melalui kebiasaan membaca ini akan menjadikan siswa untuk menggali berbagai informasi dan pengetahuan dari berbagai sumber, sehingga melalui pengetahuan yang luas akan menjadi referensi untuk menunjang siswa terhadap keterampilan menulis.

Selain dari itu, kemampuan memahami wacana mempunyia hubungan yang signifikan terhadap kemampuan menulis narasi siswa. Kemampuan memahami wacana ini sangat penting dimiliki oleh siswa, hal ini karena tidak akan bermakna siswa membaca berbagai sumber bacaan apabila siswa tidak memahami isi yang terkandung dalam teks bacaan tersebut. Artinya semua siswa harus mengerti apa yang mereka baca dan memahami teksnya sebab mereka akan tahu isi teksnya jika mereka memahami isi teks tersebut (Deka \& Amir, 2014, hlm.xx..). Sehingga melalui pemahaman terhadap isi yang terkandung dalam teks yang dibaca oleh siswa akan menunjang dalam mengembangkan keterampilan menulisnya.

Merujuk pada pemaparan di atas yang telah dikemukakan terkait hubungan antara minat membaca dan kemampuan memahami wacana terhadap keterampilan menulis, maka minat membaca dan memahami isi wacana memiliki hubungan positif dengan keterampilan menulis narasi. Artinya semakin baik minat membaca dan memahami wacana siswa maka semakin baik pula keterampilan menulis narasinya. Dan sebaliknya semakin rendah minat membaca dan memahami isi wacana maka semakin rendah pula dalam keterampilan menulis narasi.

Untuk membuktikan apakah minat membaca dan kemampuan memahami wacana dengan keterampilan menulis narasi seperti yang telah dipaparkan di atas, maka peneliti terdorong untuk melakuka pembuktian melalui penelitian dengan judul "Hubungan minat membaca dan kemampuan memahami wacana dengan keterampilan menulis narasi siswa kelas V SD Kecamatan Sukaraja".

\section{METODE}

Pendekatan yang digunakan adalah pendekatan kuantitatif dengan Metode survai (studi korelasional) yang menggambarkan tentang variabel-variabel yang diteliti, sekaligus menyelidiki hubungan antar variabel. Penelitian ini untuk mengetahui hubungan antara keterampilan menulis narasi $(\mathrm{Y})$, minat membaca $\left(\mathrm{X}_{1}\right)$ kemampuan memahami wacana $\left(\mathrm{X}_{2}\right)$. Hubungan ketiga variabel tersebut dapat diilustrasikan pada gambar sebagai berikut :

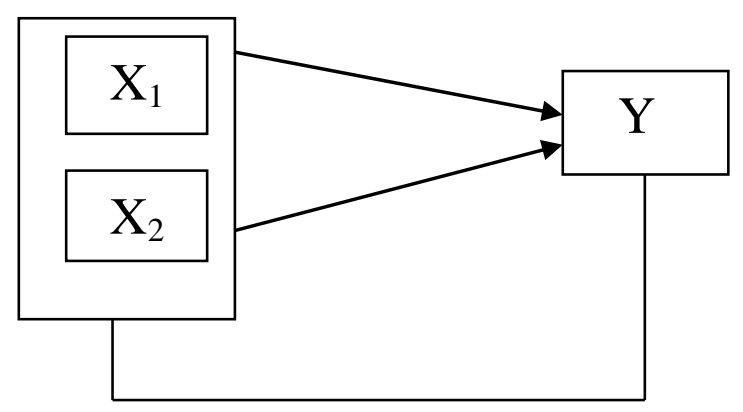

Gambar 1 Konstelasi Masalah Penelitian

Pemilihan sampel ini ditentukan berdasarkan teknik random sampling. Dari seluruh gugus satu di kecamatan sukaraja 
terpilih tiga sampel sekolah yang menjadi sasaran peneltian ini, yaitu adalah seluruh siswa kelas $\mathrm{V}$ di gugus satu Kecamatan Sukaraja yang berjumlah 112 orang.

Penilaian keterampilan menulis narasi yaitu membuat karangan berdasarkan gambar yang dipilih. Penilaian minat membaca dalam bentuk angket dengan 31 butir pernyataan. Penilaian kemampuan memahami wacana dalam bentuk tes dengan 10 butir soal.

Analisis deskriptif menyajikan tiga hal yaitu (a) penyajian data dalam bentuk distribusi frekuensi dan histogram, (b) ukuran pemusatan data digunakan untuk mengetahui gejala pusat meliputi mean (rerata, median dan modus, serta (c) ukuran penyebaran data yaitu rentang skor varians, dan simpangan baku ( standar deviasi).

Penyajian analisis deskriptif dalam penelitian ini meliputi tiga variabel yaitu : (Y) variabel keterampilan menulis narasi, $\left(\mathrm{X}_{1}\right)$ variabel minat membaca, $\left(\mathrm{X}_{2}\right)$ variabel kemampuan memahami wacana. Masingmasing variabel disajikan distribusi frekuensi dan histogram, ukuran pemusatan data, dan ukuran penyebaran.

Analisis Inferensial menyajikan tiga hal yaitu uji korelasi, korelasi ganda, dan uji signifikansi. Analisis Korelasi digunakan untuk mengetahui seberapa erat hubungan antara variabel minat membaca dan kemampuan memahami wacana dengan variabel keterampilan menulis narasi. Analisis regresi digunakan untuk menaksirkan nilai variabel y berdasarkan nilai variabel x serta taksiran perubahan y untuk setiap satuan perubahan variabel $\mathrm{x}$. Pengujian hipotesis pada penelitian ini diadakan dengan

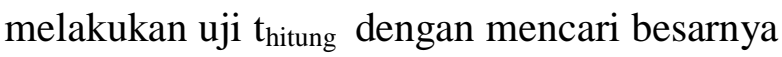
$\mathrm{t}_{\text {hitung }}$ yang akan dibandingkan dengan $\mathrm{t}_{\text {tabel. }}$. Koefisien determinasi untuk menyatakan besar kecilnya sumbangan variabel $\mathrm{X}_{1}$ dan $\mathrm{X}_{2}$ terhadap variabel Y.

\section{HASIL DAN PEMBAHASAN}

Data yang diperoleh dari tes keterampilan menulis narasi dengan membuat karangan narasi didapatkan perhitungan deskripsi data dapat diketahui nilai rata-rata $(\mathrm{M})=17,78$, Modus $(\mathrm{Mo})=18,6$, dan $\operatorname{Median}(\mathrm{Ma})=$ 17,785. Skor keterampilan menulis narasi disusun kedalam distribusi frekuensi pada tabel 1 serta disajikan dalam bentuk histogram sebagaimana ditunjukan pada tabel berikut ini:

Tabel 1

Distribusi Frekuensi Skor Keterampilan Menulis Narasi

\begin{tabular}{cccccc}
\hline $\begin{array}{c}\text { Kelas } \\
\text { Interval }\end{array}$ & $\begin{array}{c}\text { Batas } \\
\text { Bawah }\end{array}$ & $\begin{array}{c}\text { Batas } \\
\text { Atas }\end{array}$ & $\begin{array}{c}\text { Frek. } \\
\text { Absolut }\end{array}$ & $\begin{array}{c}\text { Frek. } \\
\text { Relatif }\end{array}$ & $\begin{array}{c}\text { Frek. } \\
\text { kumulatif }\end{array}$ \\
\hline $12-13$ & 11,5 & 13,5 & 9 & $10.0 \%$ & $10,0 \%$ \\
$14-15$ & 13,5 & 15,5 & 15 & $16.7 \%$ & $26,7 \%$ \\
$16-17$ & 15,5 & 17,5 & 25 & $20.0 \%$ & $46,7 \%$ \\
$18-19$ & 17,5 & 19,5 & 37 & $23.3 \%$ & $69,9 \%$ \\
$20-21$ & 19,5 & 21,5 & 15 & $16.7 \%$ & $86,6 \%$ \\
$22-23$ & 21,5 & 23,5 & 11 & $13.3 \%$ & $100 \%$ \\
\hline Jumlah & & 112 & $100 \%$ & \\
\hline
\end{tabular}

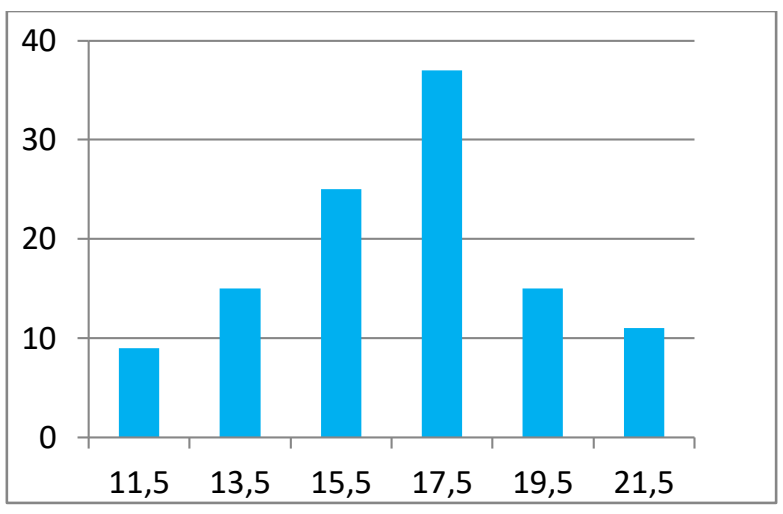

Gambar 1

Keterampilan Menulis Narasi 
Berdasarkan data tabel 1 dan data histogram 1, dari 112 sampel penelitian skor keterampilan menulis narasi yang berada di atas kelompok rata-rata sebanyak 37 orang siswa $(23,3 \%)$ dan 49 orang siswa $(46,7 \%)$ berada di bawah kelompok rata-rata sedangkan di atas rata-rata sebanyak 26 orang siswa (30\%) di atas kelompok rata-rata.

Data yang diperoleh dari tes Kemampuan memahami wacana yang terdiri dari 10 soal dengan jumlah siswa sebanyak 112 orang siswa. Skor hasil kemampuan memahami wacana didapatkan perhitungan deskripsi data dapat diketahui nilai rata-rata $(\mathrm{M})=17,13$, $\operatorname{Modus}(\mathrm{Mo})=18,21$, dan $\operatorname{Median}(\mathrm{Ma})=$ 17,31. Skor berpikir kritis disusun kedalam distribusi frekuensi pada table 2 serta disajikan dalam bentuk histogram sebagaimana ditunjukan pada tabel berikut ini:

Tabel 2

Distribusi Frekuensi Skor Kemampuan Memahami Wacana

\begin{tabular}{cccccc}
\hline $\begin{array}{c}\text { Kelas } \\
\text { Interval }\end{array}$ & $\begin{array}{c}\text { Batas } \\
\text { Bawah }\end{array}$ & $\begin{array}{c}\text { Batas } \\
\text { Atas }\end{array}$ & $\begin{array}{c}\text { Frek. } \\
\text { Absolut }\end{array}$ & $\begin{array}{c}\text { Frek. } \\
\text { Relatif }\end{array}$ & $\begin{array}{c}\text { Frek. } \\
\text { Kumulatif }\end{array}$ \\
\hline $11-12$ & 10,5 & 12,5 & 10 & $6.7 \%$ & $6,7 \%$ \\
$13-14$ & 12,5 & 14,5 & 19 & $16.7 \%$ & $23.4 \%$ \\
$15-16$ & 14,5 & 16,5 & 13 & $10.0 \%$ & $33.4 \%$ \\
$17-18$ & 16,5 & 18,5 & 29 & $30.0 \%$ & $63.4 \%$ \\
$19-20$ & 18,5 & 20,5 & 28 & $26.7 \%$ & $90.1 \%$ \\
$21-22$ & 20,5 & 22,5 & 13 & $10.0 \%$ & $100 \%$ \\
\hline Jumlah & & & 112 & $100 \%$ & \\
\hline
\end{tabular}

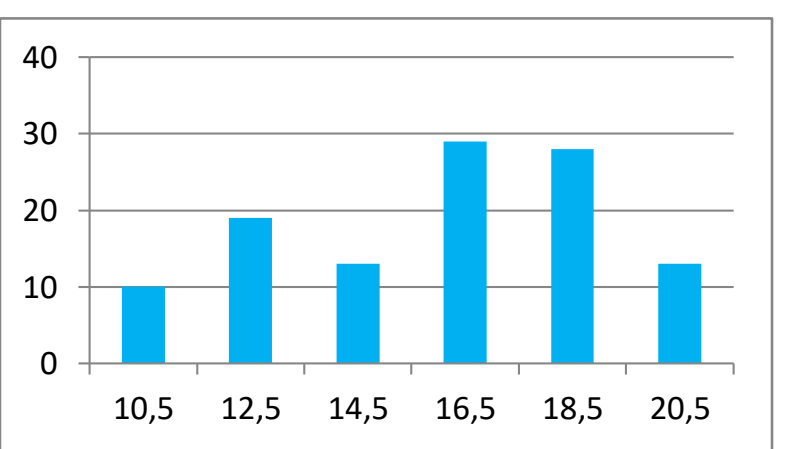

Gambar 2.

Grafik Histogram Kemampuan Memahami Wacana
Berdasarkan data tabel 2 dan grafik histogram 2 , dari 112 sampel penelitian skor kemampuan memahami wacana yang berada di atas kelompok rata-rata sebanyak 29 orang siswa $(30 \%)$ dan 42 orang siswa $(33,4 \%)$ berada di bawah kelompok rata-rata sedangkan sebanyak 41 orang siswa $(36,5 \%)$ di atas kelompok rata-rata.

Data yang diperoleh dari tes minat membaca yang terdiri dari 31 soal dengan jumlah siswa sebanyak 112 orang siswa. Skor minat membaca didapatkan perhitungan deskripsi data dapat diketahui nilai rata-rata $(\mathrm{M})=90,6$, Modus $(\mathrm{Mo})=76,16$ dan Median $(\mathrm{Ma})=86,64$. Skor minat membaca disusun kedalam distribusi frekuensi pada tabel 3 serta disajikan dalam bentuk histogram sebagaimana ditunjukan pada tabel berikut ini :

Tabel 3

Distribusi Frekuensi Skor Minat Membaca

\begin{tabular}{llllll}
\hline $\begin{array}{c}\text { Kelas } \\
\text { Interval }\end{array}$ & $\begin{array}{c}\text { Batas } \\
\text { Bawah }\end{array}$ & $\begin{array}{c}\text { Batas } \\
\text { Atas }\end{array}$ & $\begin{array}{c}\text { Frek. } \\
\text { Absolut }\end{array}$ & $\begin{array}{c}\text { Frek. } \\
\text { Relatif }\end{array}$ & $\begin{array}{c}\text { Frek. } \\
\text { Komulatif }\end{array}$ \\
\hline $70-77$ & 69,5 & 77,5 & 13 & $10.0 \%$ & $10.0 \%$ \\
$78-85$ & 77,5 & 85,5 & 26 & $26.7 \%$ & $36.7 \%$ \\
$86-93$ & 85,5 & 93,5 & 25 & $23.3 \%$ & $60 \%$ \\
$94-101$ & 93,5 & 101,5 & 25 & $23.3 \%$ & $83.3 \%$ \\
$102-109$ & 101,5 & 109,5 & 10 & $6.7 \%$ & $90 \%$ \\
$110-117$ & 109,5 & 117,5 & 13 & $10.0 \%$ & $100 \%$ \\
\hline Jumlah & & & 112 & $100 \%$ & \\
\hline
\end{tabular}

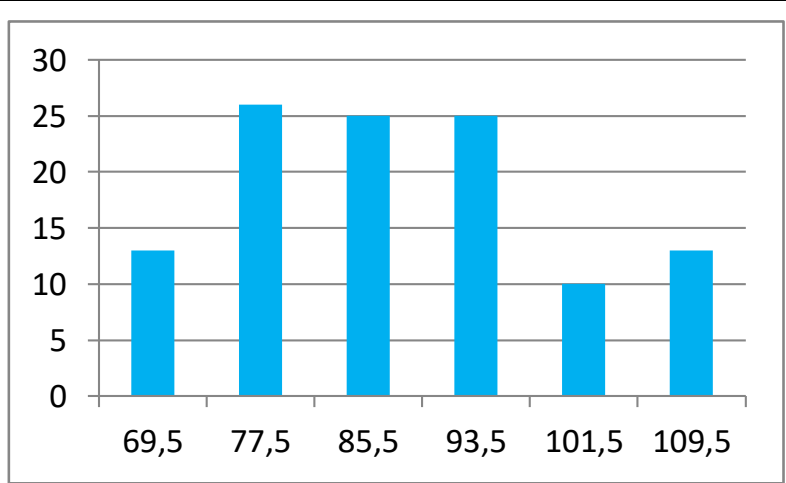

Gambar 3

Grafik Histogram Minat Membaca 
Berdasarkan data tabel 3 dan grafik histogram 3, dari 112 sampel penelitian skor minat membaca yang berada di atas kelompok rata-rata sebanyak 25 orang siswa $(23,3 \%)$ dan 39 orang siswa $(36,7 \%)$ berada di bawah kelompok rata-rata sedangkan sebanyak 48 orang siswa $(40 \%)$ di atas kelompok rata-rata.

Hipotesis pertama yang diajukan dalam penelitian ini menyatakan bahwa terdapat hubungan positif antara minat membaca dan keterampilan menulis narasi hal ini ditunjukan dengan $t_{\text {hitung }}=$ jauh lebih besar pada $t_{\text {tabel }}$ pada taraf signifikan $\alpha=0,05$ yaitu 1.701. atau $t_{\text {hitung }} 4,082>1.701$.Pola hubungan antara kedua variabel ini dinyatakan oleh persamaan regresi $\hat{Y}=$ $6.312+0.657 X 1$. Persamaan ini menunjukan bahwa hubungan minat membaca dengan keterampilan menulis narasi kelas V di SD gugus satu Kecamatan Sukaraja adalah searah (positif), hal tersebut ditunjukan pada koefisien regresi atau nilai $b$ dalam persamaan regresi tersebut yang menunjukan angka positif sebesar 0.657 yang mengandung arti bahwa setiap kenaikan minat membaca 1 satuan akan diikuti dengan kenaikan keterampilan menulis narasi mengalami penurunan sebesar 0.657 satuan. Demikian pula sebaliknya, jika minat membaca mengalami penurunan 1 satuan maka keterampilan menulis narasi akan lebih cenderung mengalami penurunan sebesar 0.657 satuan. Dan nilai koefisien a (intercept) sebesar 6.312 yang mempunyai arti apa bila tidak terdapat minat membaca diperkirakan keterampilan menulis narasi sebesar 6.132 satuan.

Hasil analisis korelasi sederhana antara minat membaca dengan keterampilan menulis narasi kelas $\mathrm{V}$ gugus satu Kecamatan Sukaraja diperoleh $\mathrm{r}$ sebesar 0,611. Dari hasil tersebut dapat disimpulkan bahwa kedua variabel tersebut kuat dan searah (Positif). Sedangkan hasil analisis koefisien determinasi antara variabel $\mathrm{X}_{1}$ dan $\mathrm{Y}$ maka $\mathrm{R}$ Square sebesar 0,373 atau $37,3 \%$. Hal ini menunjukan pengaruh positif dari minat membaca dengan keterampilan menulis narasi sebesar $37.3 \%$.

Hipotesis kedua yang diajukan dalam penelitian ini menyatakan bahwa terdapat hubungan positif dan signifikan antara kemampuan memahami wacana dan keterampilan menulis narasi hal ini ditunjukan dengan $t_{\text {hitung }}=$ jauh lebih besar pada $t_{\text {tabel }}$ pada taraf signifikan $\alpha=0,05$ yaitu 1.701. atau $t_{\text {hitung }} 3.430>1.701$.Pola hubungan antara kedua variabel ini dinyatakan oleh persamaan regresi $\hat{Y}=$ $4.952+0.139 X 2$. Persamaan ini menunjukan bahwa hubungan kemampuan memahami wacana dan keterampilan menulis narasi adalah searah (positif), hal tersebut ditunjukan pada koefisien regresi atau nilai b dalam persamaan regresi tersebut yang menunjukan angka positif sebesar 0.139 yang mengandung arti bahwa setiap kenaikan kemampuan memahami wacana 1 satuan akan diikuti dengan keterampilan menulis 
narasi mengalami penurunan sebesar 0.139 satuan. Demikian pula sebaliknya, jika kemampuan memahami wacana mengalami penurunan 1 satuan maka keterampilan menulis narasi akan lebih cenderung mengalami penurunan sebesar 0.139 satuan. Dan nilai koefisien a (intercept) sebesar 4.952 yang mempunyai arti apa bila tidak terdapat kemampuan memahami wacana diperkirakan keterampilan menulis narasi sebesar 4.952 satuan.

Hasil analisis korelasi sederhana antara kemampuan memahami wacana dan keterampilan menulis narasi diperoleh $\mathrm{r}$ sebesar 0,544. Dari hasil tersebut dapat disimpulkan bahwa kedua variabel tersebut kuat dan searah (Positif). Sedangkan hasil analisis koefisien determinasi antara variabel $\mathrm{X}_{2}$ dan Y maka R Square sebesar 0,296 atau 29,6 \%. Hal ini menunjukan pengaruh positif dari kemampuan memahami wacana dan keterampilan menulis narasi sebesar 29,6\%.

Hipotesis ketiga yang diajukan dalam penelitian ini menyatakan bahwa terdapat hubungan positif antara minat membaca dan kemampuan memahami wacana dengan keterampilan menulis narasi hal ini ditunjukan dengan $t_{\text {hitung }}=$ jauh lebih besar pada $t_{\text {tabel }}$ pada taraf signifikan $\alpha=0,05$ yaitu 1.701. atau $t_{\text {hitung }} 11.713>1.701$.Pola hubungan antara kedua variabel ini dinyatakan oleh persamaan regresi $\hat{\mathrm{Y}}=$ $1.258+0.494 \mathrm{X} 1+0.87 \mathrm{X} 2$. Persamaan ini menunjukan bahwa hubungan minat membaca dan kemampuan memahami wacana dengan keterampilan menulis narasi adalah searah (positif), hal tersebut ditunjukan persamaan regresi tersebut terlihat bahwa terdapat hubungan minat membaca dan kemampuan memahami wacana dengan keterampilan menulis narasi, hal tersebut ditunjukan pada koefisien regresi atau b1 dalam persamaan regresi tersebut yang menunjukan positif sebesar 0.494 yang mengandung arti bahwa setiap kenaikan minat membaca 1 satuan akan diikuti dengan keterampilan menulis narasi sebesar 0.494 satuan. Demikian pula sebaliknya jika minat membaca mengalami penurunan 1 satuan maka keterampilan menulis narasi akan mengalami penurunan sebesar 0.494 satuan.

Dari persamaan regesi memahami wacana terhadap keterampiln menulis narasi terlihat bahwa pengaruhnya searah (positif). Hal tersebut ditunjukan pada koefisien regresi atau nilai b2 dalam persamaan regresi tersebut yang menunjukan angka positif sebesar 0.87 yang mengandung arti bahwa setiap kenaikan memahami wacana siswa 1 satuan akan diikuti dengan kenaikan keterampilan menulis narasi sebesar 0.087 satuan. Demikian pula sebaliknya jika Kemampuan memahami wacana mengalami penurunan 1 satuan maka keterampilan menulis narasi akan mengalami penurunan sebesar 0.87 satuan.

Hasil analisis korelasi sederhana antara minat membaca dan kemampuan memahami wacana dengan keterampilan menulis narasi diperoleh $r$ sebesar 0,682. Dari hasil tersebut 
dapat disimpulkan bahwa kedua variabel tersebut kuat dan searah (Positif). Sedangkan hasil analisis koefisien determinasi antara variabel $\mathrm{X}_{2}$ dan $\mathrm{Y}$ maka $\mathrm{R}$ Square sebesar 0,465 atau $46,5 \%$. Hal ini menunjukan pengaruh positif dari minat membaca dan kemampuan memahami wacana dengan keterampilan menulis narasi sebesar 46,5\%.

Minat membaca dapat membantu meningkatkan keterampilan menulis narasi, melalui minat membaca siswa akan mempunyai berbagai sumber informasi yang akan membantu siswa dalam mengembangkan tulisan yang dibuatnya sehingga menghasilkan karya tulisan yang bermakna. Hal ini karena melalui kegiatan membaca akan memberikan dampak yang sangat besar bagi perkembangan intelektual. Menurut Darmono menyatakan bahwa minat baca merupakan kecenderungan jiwa yang mendorong seseorang berbuat sesuatu terhadap membaca. Jadi minat membaca diperlukan dalam mengkonstruksi pengetahuan sehingga siswa yang memiliki pengetahuan tingkat tinggi.

Kemampuan memahami wacana memberikan konstribusi yang cukup signifikan terhadap keterampilan menulis narasi, dimana melalui kemampuan memahami wacana yang baik akan menjadikan siswa dapat memahami secara utuh setiap informasi yang dibacanya. Dalam hal ini aktivitas membaca dilakukan tidak hanya membaca secara sekilas tanpa mempertimbangkan pemahaman terhadap isi bacaan. Sehingga pemahaman yang menjadi pokok dalam kegiatan membaca. Hal ini sebagaimana pendapat Pado dan Plourde menyatakan "state that comprehension is the interaction among aword identification, prior knowladge, comprehension strategies and engagement. Its means that all student have to understand what they read in order to comprehend and understand the text. Artinya semua siswa harus mengerti apa yang mereka baca dan memahami teksnya sebab mereka akan tahu isi teksnya jika mereka memahami isi teks tersebut. Sehingga melalui kemampuan memahami wacana akan memudahkan siswa untuk mengembangkan karya tulis yang dibuatnya karena siswa tersebut telah mempunyai pengetahuan yang luas dari berbagai sumber bacaan.

Minat membaca dan kemampuan memahami wacana bersama-sama memiliki hubungan positif dengan keterampilan menulis narasi. Dengan demikian, variabel minat membaca dan kemampuan memahami wacana merupakan dua faktor yang harus diperhatikan untuk meningkatkan keterampilan menulis narasi.. Berdasarkan hasil pengujian statistik menunjukan bahwa minat membaca dan kemampuan memahami wacana memberikan konstribusi yang cukup signifikan terhadap keterampilan menulis narasi, dimana semkin tinggi minat membaca semakin tinggi pula keterampilan menulis narasi siswa. Sebaliknya semakin rendah minat membaca maka semakin rendah pula keterampilan menulis narasi siswa. Dan 
Kemampuan memahami wacana yang baik/positif akan membantu siswa untuk mengembangkan konsep tulisan yang dibuatnya sehingga menjadi suatu karya tulis yang baik. Dengan demikian dapat dijelaskan bahwa keterampilan menulis narasi siswa salah satu faktor yang dapat ditentukan melalui minat membaca dan kemampuan memahami wacana.

\section{REFERENSI}

Artamita, Ni Luh Putu Sri. Meningkatkan Keterampilan Siswa Menulis Surat Dinas Melalui Metode Pemberian Tugas di Kelas V SD Impres 12 Bajawali, Jurnal Kreatif Tadulako, Vol. 5 (6), 2017.

Deka, Tri \& Amir, Zainuddin. Developing Senior High School Student's Reading Comprehension By Using Proposition Support Outline", Journal JELT State University Of Padang, Vol. 3 (1), 2014.

Gallint Rahadian dkk., Peranan Perpustakaan Sekolah Dalam Meningkatkan Budaya Gemar Membaca, Jurnal Kajian Informasi \& Perpustakaan, Vol.2 (1), 2014.

Herlina, Peningkatan Keterampilan Membaca Pemahaman Bahasa Inggris Melalui Metode SQ4R, Jurnal Ilmiah VISI PAUDNI, PGSD UNJ, Vol. 11 (1), 2016.

Kompas.Com, "Minat Baca Indonesia Ada di Urutan 60 Dunia," Online; http://2016/08/29/07175131/Minat.Baca .Indonesia.Ada.Di.Urutan.Ke-60.Dunia (Diakses 05 Oktober 2016).

Maryuingsih. Hubungan minat membaca dengan keterampilan menulis narasi siswa kelas IV Sekolah Dasar segugu kecamatan Kraton Yogtakarta tahun 2013/2014. Skripsi. Jogyakarta: Universitas Negeri Yogyakarta,2014.
Nurgiantoro, Burhan. 2012. Penilaian Pembelajaran Bahasa Indonesia Berbasis Kompetensi. Yogyakarta: BPFE.

Satini, Ria. Hubungan Minat Baca Dan Motivasi Belajar Dengan Keterampilan Menulis Berita Siswa Kelas Viii Smp Negeri 24 Padang" Jurnal Bahasa, Sastra Dan Pembelajaran Vol. 2 (1) 2015.

Suharmono Kasiyun, Upaya Meningkatkan Minat Baca Sebagai Sarana Untuk Mencerdaskan Bangsa, Jurnal Pena Indonesia (JPI), Vol 1 (1), 2015.

Undang-Undang RI No 20 Tahun 2003 Tentang Sisdiknas.

Zulela. 2013. Terampil Menulis di Sekolah Dasar. Tangerang: PT Pustaka Mandiri. 